\title{
Cutaneous tuberculous gummas in a patient with polymyositis
}

\author{
Tuberculose cutânea gomosa em um paciente com polimiosite
}

\author{
Guilherme Almeida Rosa da Silva ${ }^{1}$ \\ Ricardo de Souza Carvalho ${ }^{3}$ \\ Marcelo Costa Velho Mendes de Azevedo5
}

\author{
Rogerio Neves Motta \\ Omar Lupi ${ }^{4}$ \\ Fernando Raphael de Almeida Ferry ${ }^{6}$
}

\begin{abstract}
Metastatic tuberculous abscesses or cutaneous tuberculous gummas occur mostly by reactivation of ancient cutaneous foci and is triggered mainly by pharmacological immunosuppression, diabetes mellitus, alcoholism or acquired immunodeficiency syndrome. The present case report refers to a 33-year-old male patient with polymyositis and a previous diagnosis of treated pulmonary tuberculosis. He presented cutaneous abscesses and fever months after the tuberculosis regimen. The patient was diagnosed as metastatic tuberculous abscesses associated with immunosuppression as result of polymyositis treatment.

Keywords: Adrenal cortex hormones; Immunosuppression; Mycobacterium tuberculosis; Myositis; Polymyositis; Tuberculosis, cutaneous

Resumo: Abscesso tuberculoso metastático ou goma tuberculosa cutânea, ocorre principalmente pela reativação de surtos cutâneos precoces desencadeados principalmente por imunodepressão farmacológica, diabetes mellitus, alcoolismo ou síndrome da imunodeficiência adquirida. O presente caso relatado refere-se a um paciente do sexo masculino de 33 anos portador de polimiosite e com diagnóstico prévio de tuberculose pulmonar tratada. Apresentou, meses depois do tratamento para tuberculose, abscessos cutâneos e febre. Após a investigação clínica foi diagnosticado como portador de tuberculose gomosa cutânea associada à imunodepressão consequente ao tratamento de polimiosite.

Palavras-chave: Corticosteróides; Imunossupressão; Miosite; Mycobacterium tuberculosis; Polimiosite; Tuberculose cutânea
\end{abstract}

Received on 17.01.2011.

Approved by the Advisory Board and accepted for publication on 15.01.2012.

* Study carried out at the Teaching Hospital, Federal University of Rio de Janeiro (Hospital Universitário Gaffrée e Guinle. Universidade Federal do Estado do Rio de Janeiro - HUGG-UNIRIO) - Rio de Janeiro (RJ), Brazil.

Conflito de interesse: Nenhum / Conflict of interest: None

Suporte financeiro: Nenhum / Financial funding: None

MD - Temporary Professor of Semiology. Teaching Hospital, Federal University of Rio de Janeiro (Hospital Universitário Gaffrée e Guinle. Universidade Federal do Estado do Rio de Janeiro - HUGG-UNIRIO) - Rio de Janeiro (RJ), Brazil.

MD - Assistant Professor of Internal Medicine. Teaching Hospital, Federal University of Rio de Janeiro (Hospital Universitário Gaffrée e Guinle. Universidade Federal do Estado do Rio de Janeiro - HUGG-UNIRIO) - Rio de Janeiro (RJ), Brazil.

3 Master's Degree in Medicine - Member of the Tenth Infirmary Staff. Teaching Hospital, Federal University of Rio de Janeiro (Hospital Universitário Gaffrée e Guinle. Universidade Federal do Estado do Rio de Janeiro - HUGG-UNIRIO) - Rio de Janeiro (RJ), Brazil.

MD - Adjunct Professor of Dermatology. Teaching Hospital, Federal University of Rio de Janeiro (Hospital Universitário Gaffrée e Guinle. Universidade Federal do Estado do Rio de Janeiro - HUGG-UNIRIO) - Rio de Janeiro (RJ), Brazil.

Master's Degree in Medicine - Assistant Professor of Semiology. Teaching Hospital, Federal University of Rio de Janeiro (Hospital Universitário Gaffrée e Guinle. Universidade Federal do Estado do Rio de Janeiro - HUGG-UNIRIO) - Rio de Janeiro (RJ), Brazil.

MD - Associate Professor II of Internal Medicine and AIDS. Teaching Hospital, Federal University of Rio de Janeiro (Hospital Universitário Gaffrée e Guinle. Universidade Federal do Estado do Rio de Janeiro - HUGG-UNIRIO) - Rio de Janeiro (RJ), Brazil. 


\section{INTRODUCTION}

Tuberculosis is an infectious disease caused by Mycobacterium tuberculosis and may also be caused by other species of the same genus such as M. bovis, M. africanum, M. microti or M. canetti. ${ }^{1}$ These infectious agents are aerobic bacilli with a thick waxy cell wall composed of mycolic acid, which renders them acid-fast. $^{2}$

Pulmonary involvement is the most common form of the disease. Nevertheless, several organ systems may also be affected by hematogenous dissemination, causing extrapulmonary tuberculosis. The extrapulmonary tuberculosis presentations have probably been increasing as a result of AIDS and the increased use of immunosuppressive drugs. ${ }^{1}$

Cutaneous tuberculosis is responsible for about $2.1 \%$ of all cases of tuberculosis. The greatest incidence occurs in people on a low income. With the advent of AIDS there was a rise in incidence probably due to a process of reactivation of latent tuberculosis in immunocompromised people by an increase in the number of bacilli that are resistant to treatment or because immunosuppression facilitates infection by less virulent strains. ${ }^{1}$

\section{CASE REPORT}

A 33-year-old male patient resident of Manguinhos - Rio de Janeiro - Brazil was diagnosed 18 months ago with polymyositis and was irregularly taking methotrexate $(15 \mathrm{mg} /$ weak) with prednisone ( 40 $\mathrm{mg} /$ day); however, he failed to attend medical followup visits regularly. One year ago, he was hospitalized with pulmonary tuberculosis. He was prescribed rifampicin, isoniazid and pyrazinamide and completed a six-month treatment period.

Six months later, he was admitted at the Hospital with painful warm nodules of various sizes on his body in addition to gummatous lesions developed two months earlier (Figures 1, 2 and 3). He presented intermittent fever which responded to metamizole. There was throbbing pain in his limbs, aggravated by movement and alleviated by resting. He also complained of muscle weakness in pectoral and pelvic girdle.

At admission, he had tachypnea, tachycardia and fever. Lymphadenopathy was absent and the blood pressure was normal. The laboratory tests showed leukocytosis $(21,100$ leukocytes), thrombocytosis $(573,000$ platelets) and normocytic normochromic anemia. Lactate dehydrogenase (LDH) levels were $515 \mathrm{U} / \mathrm{I}$ and creatine phosphokinase (CPK) 282 IU/1. Chest x-ray revealed no abnormalities. During hospitalization, leukocytosis, thrombocytosis and normocytic normochromic anemia persisted, as well as increased LDH levels. Creatine phosphokinase returned to normal levels.

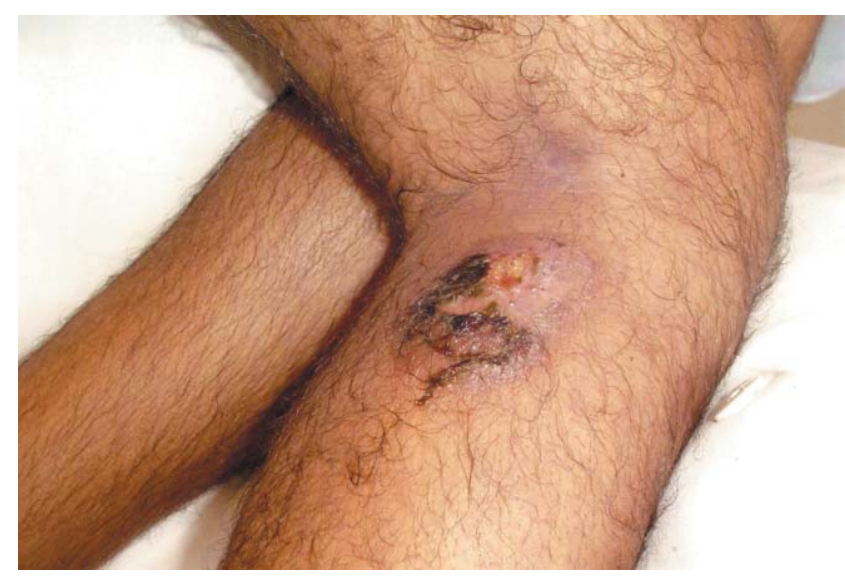

Figure 1: Gummatous lesion on the posterior region of the upper third of the right leg

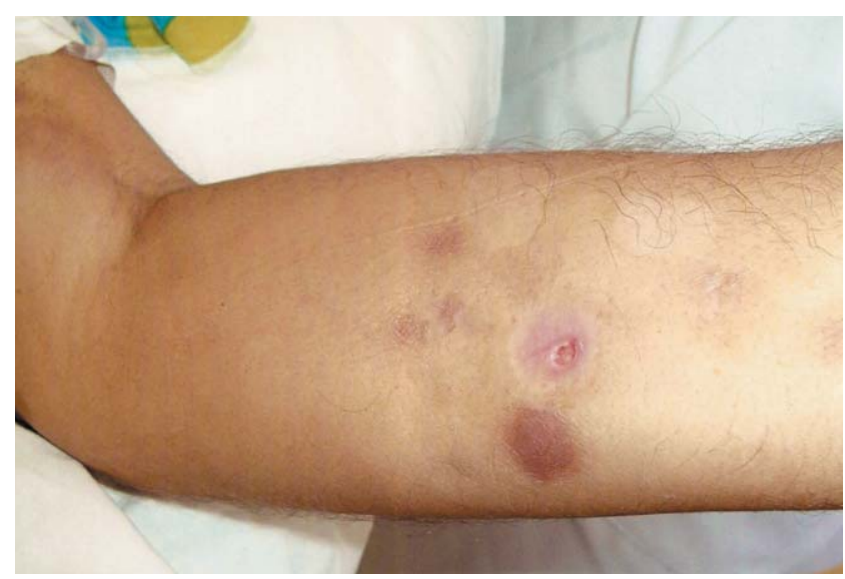

FIGURE 2: Ulcerated lesion on the internal surface of the left forearm

The differential diagnosis of the nodular disease mainly considered myositis and vasculitis, methotrexate-related panniculitis, Weber-Christian disease, subcutaneous panniculitis-like T-cell lymphoma, erythema nodosum, bacterial, fungal and mycobacterial infections.

At admission antibiotic therapy with oxacillin was initiated against infection by Staphylococcus. However, no specimen has confirmed the suspicion of diagnosis. These results hampered the investigation for presence of staphylococci bacteria and made the decision to maintain or not the antibiotics difficult. The patient's fever and skin rash persisted despite the therapy. On the seventh day of treatment, the antibiotic was changed to vancomycin at $500 \mathrm{mg}$ qid intravenously for 14 days; no improvement occurred in the patient's clinical condition.

The material collected from the lesions was studied for histopathology patterns, bacterioscopy and culture studies.

Ultrasound confirmed a subcutaneous structur- 


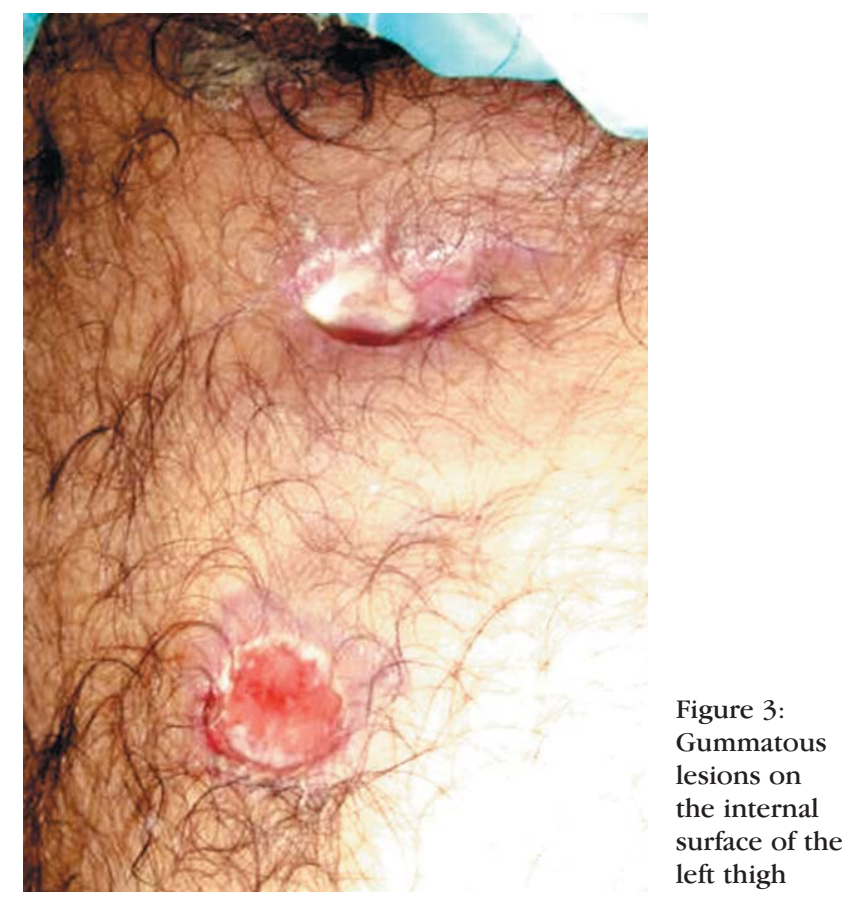

al alteration on the posterior region of the upper third of the right leg, with $8 \mathrm{~cm}$ in size and without liquid. The possibility of purulent material being accumulated inside the lesion could not be discarded.

Skin histopathology studies revealed acanthosis, edema of the reticular dermis, and mild infiltrate of lymphocytes with some neutrophils around vessels and skin adnexa. Panniculitis was suggested by the presence of subcutaneous necrosis of adipocytes, deposits of fibrinoid material and hyaline eosinophilic strands. Initially, aspirated secretion from the lesions was negative for acid-fast bacilli.

One week later, a new sample showed acid-fast bacilli $(+++)$. Rifampicin $600 \mathrm{mg} \mathrm{qd}$, isoniazide 400 $\mathrm{mg}$ qd, pyrazinamide $2 \mathrm{~g}$ qd and ethambutol $1.2 \mathrm{~g}$ qd were initiated. Within a five-day treatment period the patient improved considerably, the fever disappeared and he was discharged. Culture studies revealed growth of Mycobacterium tuberculosis. Lesions were totally cured after 6 months.

\section{DISCUSSION}

Cutaneous tuberculosis is a rare disease with specific clinical features and natural history. Clinical manifestation and following events, may depend on multiple factors such as how bacilli accessed the skin; the strain's virulence; number of inoculated bacilli; immune state of the patient and the relation of Mycobacterium with the anatomical region affected. ${ }^{3}$

Skin lesions can be divided according to exposure in primary and secondary lesions, by local inoculation or by distant dispersion, respectively. Tuberculids are a hypersensitivity reaction to a distant focus of infection. ${ }^{4}$

Diagnosis of cutaneous tuberculosis may be achieved by direct microscopy, PCR, culture and histopathology study of a biopsy specimen. Chest $\mathrm{x}$ ray with pulmonary involvement, active or not, as well as positive PPD may help the diagnosis. ${ }^{5}$

The patient had a previous diagnosis of polymyositis. It causes an autoimmune chronic inflammation of the muscles with marked pain, weakness and/or loss of muscle mass in the proximal musculature, particularly in the shoulder and pelvic girdle. The standard treatment is pharmacologic immunosuppression.

The simultaneously presentation of polymyositis and cutaneous mycobacteriosis is rare. After a literature review we have found 3 similar cases of patients with cutaneous tuberculosis plus dermatomyositis and one case of neutrophilic tuberculous panniculitis in a patient with polymyositis. The immunosuppressive treatment seems to be responsible for the presentation of cutaneous tuberculosis. Besides, because of the number of case reports, a study is necessary to evaluate the direct relationship between polymyositis and cutaneous tuberculosis. ${ }^{6.9}$

In the present case, the treatment of polymyositis may have induced the development of pulmonary tuberculosis; and one year later the onset of cutaneous disease was observed. During hospitalization, chest x-ray and CT scanning showed no evidence of tuberculosis activity. The lack of response of the tuberculin test and the absence of granuloma histopathology findings were probably due to immunosuppression of the cell-mediated immunity. An additional investigation of secretion showed acid-fast bacilli $(+++)$ and growth of Mycobacterium tuberculosis in culture. The diagnosis of cutaneous metastatic tuberculous abscess, a form of tuberculosis that results from reactivation of primary foci, was established from the presence of subcutaneous, multibacillary abscesses that formed fistulae and drained spontaneously. ${ }^{10}$

The standard RIPE regimen for six months has been shown to be effective in these forms of the disease. $\square$ 


\section{REFERENCES}

1. Kasper DL, Braunwald E, Fauci AS, Hauser SL, Longo DL, Jameson JC, organizadores. Harrison Medicina Interna. Volume I. 17. ed. Rio de Janeiro: McGraw Hill; 2008. Capítulo 158, Tuberculose; p. 1006-20.

2. Cotran RS, Kumar V, Robbins ST, organizadores. Patologia. Bases patológicas das doenças. 7 ed. Rio de Janeiro: Elsevier; 2005. Cap 8, Doenças infecciosas; p. 397.

3. Azulay RD, Azulay DR. Dermatologia. 5. ed. Rio de Janeiro: Guanabara Koogan; 2008. p, 337.

4. Rabello FE, Fraga S. Atlas de Dermatologia. Rio de Janeiro: Guanabara Koogan; 1970. p.176-283.

5. Hinrichsen SL, Moura LV, Arraes LC, Reis L, Lamprea D, Gava RK. Tuberculose cutânea e AIDS: relato de um caso. An Bras Dermatol. 1996;71:511-4.

6. Kim JE, Ko JY, Bae SC, Ro YS. Tuberculous cellulitis as a manifestation of miliary tuberculosis in a patient with malignancy-associated dermatomyositis. J Am Acad Dermatol. 2011;65:450-2.

7. Fujita M, Arakawa K, Mizuno S, Wakabayashi M, Totani Y, Demura Y, Ameshima S, et al. A case of cutaneous tuberculosis under steroid \& immunosuppressant therapy for dermatomyositis. Kekkaku. 2002;77:465-70.
8. Algayrès JP, Mayaudon H, Godeau B, Schill H, Valmary J, Maurel C, et al Mycobacterium kansasii extensive subcutaneous infection in dermatomyositis. Ann Med Interne (Paris). 1990;141:633-5.

9. Langenberg A, Egbert B. Neutrophilic tuberculous panniculitis in a patient with polymyositis. J Cutan Pathol. 1993;20:177-9.

10. Lopes AJ, Capone D, Mogami R, Tessarollo B, da Cunha DL, Capone RB, et al. Tuberculose extrapulmonar: aspectos clínicos e de imagem. Pulmão RJ. 2006;15:253-61

MAILING ADDRESS:

Fernando Raphael de Almeida Ferry

Rua Mariz e Barros, 775.

Tijuca

20270004 Rio de Janeiro, RJ.

E-mail:ferry@unirio.br

How to cite this article: da Silva GAR, Motta RN, Carvalho RS, Lupi O, Azevedo MCVM, Ferry FRA. Cutaneous tuberculous gummas in a patient with polymyositis. An Bras Dermatol. 2013;88(1):98-101. 